\title{
Simultaneous Voltammetric Determination of Dypirone and Paracetamol with Carbon Paste Electrode and Multivariate Calibration Methodology
}

\author{
Tatiane Skeika, Mariane Ferreira de Faria, Noemi Nagata and Christiana A. Pessoa*
}

Departmento de Química, Universidade Estadual de Ponta Grossa, 84030-900 Ponta Grossa-PR, Brazil

\begin{abstract}
Esse artigo descreve a determinação simultânea de dipirona (DIP) e de paracetamol (PAR) utilizando a técnica de Voltametria de Pulso Diferencial (VPD) e eletrodo de pasta de carbono não modificado. Devido à sobreposição dos picos voltamétricos de DIP e PAR, a metodologia de calibração multivariada baseada na Regressão de Mínimos Quadrados Parciais (PLSR) foi proposta. O conjunto de voltamogramas obtidos na presença de ambos os analitos em diferentes concentrações foi pré-processado pelos dados centrados na média. Para escolha do número de componentes principais, um procedimento de validação cruzada foi empregado, sendo que quatro componentes principais foram necessárias para obtenção dos menores valores de PRESS (Prediction Residual Error Sum of Squares). Esse modelo explicou aproximadamente 95,5\% da variância do conjunto de dados. Os dados obtidos utilizando-se esse modelo mostraram uma alta correlação entre as concentrações reais e previstas. Entretanto, para baixas concentrações do PAR, os erros relativos aumentaram para 25\%. Comparando-se os valores de RMSEP (Root Mean Square of Error Prediction), entre PAR e DIP, foi observado que este foi menor para DIP, provavelmente devido a maior quantidade de informação analítica apresentada pelos voltamogramas desse analito quando comparado ao processo redox de PAR, o qual devido a sua oxidação irreversível apresenta apenas um único pico.
\end{abstract}

This paper shows the simultaneous electrochemical determination of dypirone (DIP) and paracetamol (PAR) by differential pulse voltammetry technique (DPV) using an unmodified carbon paste electrode. Because of the overlapping of the voltammetric peaks of DIP and PAR, the multivariate calibration methodology based on Partial Least Square Regression (PLSR) was proposed. The data pre-treatment used in this process was mean centering and to choose the principal component number a cross validation procedure was used (leave-one-out). Four principal components were necessary to obtain the lowest PRESS (Prediction Residual Error Sum of Squares). The statistics showed that this model explains approximately $95.5 \%$ of the variance from the data set. Using this model, high correlation between real and predicted concentrations was observed. However, for low concentrations of PAR the relative error increased to 25\%. Comparing RMSEP (Root Mean Square of Error Prediction) between PAR and DIP, it was observed that it was lower for DIP probably due to higher analytical information in the voltammograms for this analyte when compared to the electrochemical process of PAR, which presented only one potential peak due to its irreversible oxidation.

Keywords: paracetamol, dypirone, carbon paste electrode, differential pulse voltammetry and multivariate calibration methodology

\section{Introduction}

The development of analytical techniques for the rapid analysis of pharmaceuticals is important for quality and medical control. Due to this fact, a rigorous method of quality control of pharmaceutical fabrication is demanded.

*e-mail: christiana.pessoa@pq.cnpq.br
Many analytical purposes in simultaneous analysis of pharmacological species are based on modern instrumental techniques, such as high performance liquid chromatography (HPLC), ${ }^{1-3}$ gas chromatography ${ }^{4}$ and capillary electrophoresis, ${ }^{5-7}$ besides spectrofluorometry and chemiluminescence. ${ }^{8-10}$ However, these techniques are generally expensive and time-consuming, so it becomes very difficult to establish an online system. So, there is a great interest in the development of new analytical 
methods for simultaneous determination of pharmaceuticals without the necessity of a previous separation of the sample components, besides being rapid and with low cost. To overcome these limitations, electrochemical methods, such as voltammetric ones were extensively used for their accuracies, precisions, simplicities and possibilities of analysis without tedious sample pre-treatment. ${ }^{11,12}$

However, the quantification of two or more components of a pharmaceutical sample using electrochemical techniques is generally a challenge task since most of the active components tend to oxidize or reduce at potentials extremely close which hampers their simultaneous determination. The association of electrochemical methods, such as voltammetric techniques using unmodified carbon electrodes with multivariate calibration methods eliminates the need for previous separations and permits simultaneous determination in the presence of analytical signal interference. The three most commonly used multivariate calibration methods are multiple linear regression (MLR), principal component regression (PCR), and partial leastsquares regression (PLSR). ${ }^{13-15}$ These methods constitute a powerful statistical tool for factor analysis and have been mostly applied to the simultaneous multicomponent analysis of mixtures by spectroscopy, chromatography, and voltammetric methods. ${ }^{16-20}$

Paracetamol or acetaminophen (Figure 1A) is a popular analgesic and antipyretic agent. Its action is similar to aspirin and it is an appropriate alternative for patients who are sensitive to acetylsalicylic acid. ${ }^{21}$ Overdose ingestions of acetaminophen lead to accumulation of toxic metabolites, which cause severe and sometimes fatal hepatotoxicity and nephrotoxicity. ${ }^{22,23}$ This drug is available in different dosage forms of tablets, capsules, suspensions and suppositories and sometimes it is present along with other analgesic agents such as dypirone. For quantification of paracetamol in pharmaceutical products, the American Pharmacopoeia recommends liquid chromatography as the official method<smiles>CC(=O)Nc1ccc(O)cc1</smiles><smiles>Cc1c(N(C)CS[18OH])c(=O)n(-c2ccccc2)n1C</smiles>

(A)

(B)

Figure 1. Chemical structures of: (A) paracetamol ( $N$-acetyl-paminophenol, 4-acetamidophenol); (B) dypirone (sodium salt of the 1-phenyl-2,3-dimethyl-4-methyl aminomethane sulfonate-5pyrazolone). while the Brazilian Pharmacopoeia uses a spectrophotometric technique. ${ }^{24,25}$ Moreover, there are many studies described in the literature using different analytical techniques for determination of this drug. ${ }^{26-30}$ Some electrochemical methods have been used for analysis of paracetamol, ${ }^{31-33}$ specially the voltammetric ones using chemically modified electrodes in order to improve the sensitivity. ${ }^{34,35}$

Dypirone (Figure 1B), is a water soluble white crystalline powder which also presents analgesic and antipyretic activity. The methods commonly used for dypirone determination in various pharmaceutical formulations are based on its reaction with iodide. ${ }^{25}$ Spectrophotometric methods such as UV-Vis absorption, ${ }^{36}$ fluorescence ${ }^{37}$ and chemiluminescence ${ }^{38}$ are frequently reported for dypirone determination. However, different from paracetamol, the electrochemical reaction and its determination using electroanalytical techniques has been less investigated. ${ }^{39-41}$ Matos et al. ${ }^{39}$ proposed a flow injection analysis based on a multi-channel detection system for simultaneous amperometric determination of dypirone, ascorbic acid, dopamine and epinephrine using an array of modified microelectrodes, together with multivariate calibration analysis. The same research group developed a flow cell containing a gold electrode from recordable compact discs for the determination of dypirone in pharmaceutical formulations. ${ }^{39}$

This paper reports the simultaneous electrochemical determination of dypirone (DIP) and paracetamol (PAR) by differential pulse voltammetry technique (DPV) using an unmodified carbon paste electrode. Because the voltammetric peaks of DIP and PAR overlaps, the multivariate calibration methodology based on Partial Least Square Regression (PLSR) was proposed. The data pre-treatment used in this process was mean centering and to choose the number of principal components a cross validation procedure was used (leave-one-out).

\section{Experimental}

\section{Preparation of the carbon paste electrodes}

The carbon paste electrode (CPE) was prepared by mixing the analytical grade graphite (Fluka) and about two drops of $\mathrm{Nujol}^{\circledR}$, added in order to get a homogeneous paste. We used the carbon paste electrode because its cost (it is cheaper than other carbon based electrodes, such as the glassy carbon electrode) and the facility of its preparation. Some initial tests were realized in order to optimize the quantity of mineral oil in the paste. The different electrodes prepared were analyzed in presence of the analytes in a fixed concentration. Best results (with more defined 
voltammetric peaks) were obtained with approximately $12 \%$ of mineral oil. As the carbon paste electrode had reproducibility problems, we tried to use the same carbon paste prepared for all measurements. The obtained paste was placed in a homemade electrode which consisted of a $1 \mathrm{~mm}$ deep cavity in contact with a carbon rod having a $0.5 \mathrm{~cm}$ diameter connected to a copper electrode for electrical contact, fused to a plastic tube.

\section{Electrochemical measurements}

All the voltammetric measurements (cyclic voltammetry and differential pulse voltammetry) were carried out using a $10 \mathrm{~mL}$ capacity electrochemical cell with the conventional three electrode system: a Pt wire as a counter electrode, an $\mathrm{Ag} / \mathrm{AgCl}$ electrode as the reference and the modified carbon paste electrodes as working electrodes. The potential range analyzed was from $-0.4 \mathrm{~V}$ to $0.4 \mathrm{~V} v s$. $\mathrm{Ag} / \mathrm{AgCl}$, with scan rates in the range between $10 \mathrm{mV} \mathrm{s}^{-1}$ and $100 \mathrm{mV} \mathrm{s}^{-1}$. Solutions of various $\mathrm{pH}$ were used, adjusted with $\mathrm{HCl}$ and $\mathrm{KOH}$ in a $0.5 \mathrm{~mol} \mathrm{~L}^{-1} \mathrm{KCl}$ (different supporting electrolytes were also tested, such as $\mathrm{NaCl}$ and $\mathrm{LiCl}$ ). The response of the electrode in the presence of paracetamol (PAR) and dypirone (DIP) was also studied by cyclic voltammetry in $\mathrm{KCl}$ solutions at different $\mathrm{pH}$. Several concentrations of PAR and DIP were used to obtain a calibration curve in the range between $2.5 \times 10^{-5}$ and $1.5 \times 10^{-3} \mathrm{~mol} \mathrm{~L}^{-1}$ in a potentiostat / galvanostat Palm Sens 3.7 model, connected to a microcomputer for data acquisition.

\section{Multivariate calibration methodology}

A PC/Pentium IV microcomputer equipped with the mathematical software MATLAB for Windows (version 4.2, distributed by MathWorks) and PLS-toolbox (version 1.5, distributed by Eigenvector Research) was employed to obtain the PLSR models. For the processing of the voltammetric data using multivariate calibration, a calibration set consisting of 25 synthetic samples were prepared. These samples were obtained by adding known amounts of working solutions of dypirone an paracetamol in a concentration of $1.0 \times 10^{-2} \mathrm{~mol} \mathrm{~L}^{-1}$ in $\mathrm{NaCl} 0.5 \mathrm{~mol} \mathrm{~L}^{-1}$. The final concentration of these solutions varied between $1.0 \times 10^{-4}$ and $5.0 \times 10^{-4} \mathrm{~mol} \mathrm{~L}^{-1}$. All the solutions were prepared with distilled water and all chemicals used were of analytical-reagent grade. The differential pulse voltammograms were obtained in the range of -0.1 and $1.1 \mathrm{~V}$ vs. $\mathrm{Ag} / \mathrm{AgCl}$.

The experimental design used to develop the multivariate calibration model for dypirone and paracetamol is presented in Figure 2 ( ) The following points were obtained in

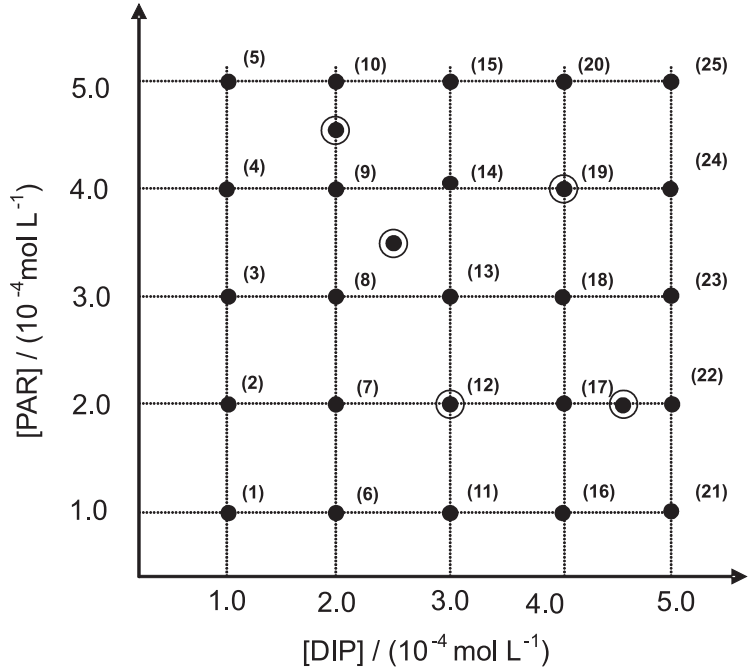

Figure 2. Composition of synthetic mixtures of paracetamol and dypirone: (๑) samples used for calibration set; (๑) samples used for external validation.

duplicate: $1,3,5,11,13,15,21,23$ and 25 . The validation set was created by random selection of 5 samples (also obtained in duplicate) from the experimental design, also shown in Figure $2\left({ }^{\circ}\right)$.

\section{Results and Discussion}

Cyclic voltammetric study of paracetamol and dypirone with carbon paste electrode

Firstly, the electrochemical responses of dypirone (DIP) and paracetamol (PAR) were characterized by cyclic voltammetry using a carbon paste electrode (Figures 3A and 3B).

As can be seen in Figure 3A, PAR exhibits one well defined anodic peak with Epa (anodic peak potential) at $0.77 \mathrm{~V} v$ s. $\mathrm{Ag} / \mathrm{AgCl}$ (pH 6.0) and a poorly defined cathodic peak at Epc $=0.10 \mathrm{~V}$ which are similar to that observed for an unmodified glassy carbon electrode. ${ }^{42}$ Kissinger et al. ${ }^{43,44}$ deeply investigated the electrochemical oxidation of paracetamol through cyclic voltammetric studies. The first reaction step is an electrochemical oxidation involving two electrons and two protons to generate $N$-acetyl-p-quinoneimine. All subsequent reaction steps are non-electrochemical, but $\mathrm{pH}$-dependent, processes. For oxidations at $\mathrm{pH}$ values higher than 6 , the final product is a benzoquinone.

The electrochemical oxidation of DIP presented one reversible pair with $\mathrm{Epa}_{1}=0.58 \mathrm{~V}$ and $\mathrm{Epc}_{1}=0.53 \mathrm{~V}$ $\left(\mathrm{Ep}_{1 / 2}=0.55 \mathrm{~V}\right)$ and two more irreversible anodic peaks with $\mathrm{Epa}_{2}=0.43 \mathrm{~V}$ and $\mathrm{Epa}_{3}=1.00 \mathrm{~V}$, as shown in Figure 3B. Perez-Ruiz et al. ${ }^{41}$ also observed the same electrochemical 

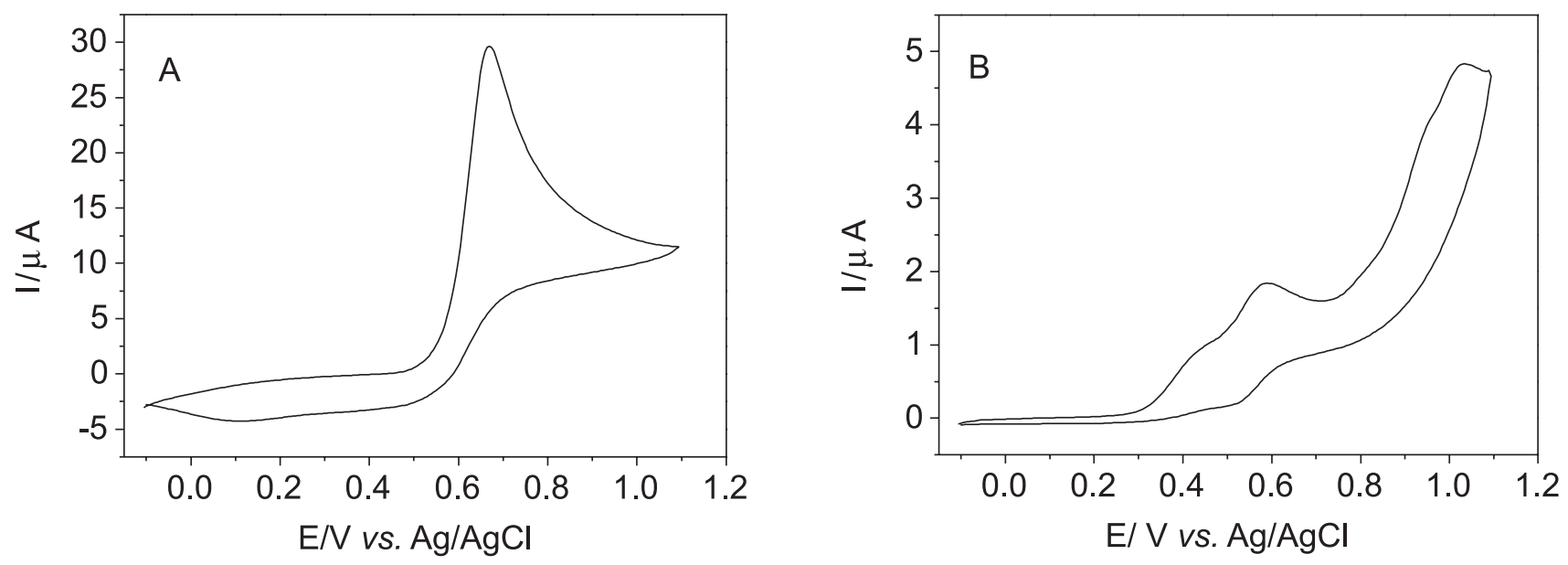

Figure 3. Cyclic voltammograms of (A) paracetamol and (B) dypirone, (concentration of $1.0 \times 10^{-3} \mathrm{~mol} \mathrm{~L}^{-1}$ ) obtained using a carbon paste electrode in $\mathrm{NaCl} 0.5 \mathrm{~mol} \mathrm{~L}^{-1}$ (pH 6.0). Potential range of: $-0.1 \mathrm{~V}$ to $1.1 \mathrm{~V}$ vs. $\mathrm{Ag} / \mathrm{AgCl}$.

behavior for dypirone using a glassy carbon electrode and a carbon paste electrode respectively. According to Teixeira et al. ${ }^{45}$ the first electrochemical oxidation peak of the dypirone is related to the methylamino- $\mathrm{N}$ methanesulphonate group.

The analytical parameters (LOD, Sensitivity, Linear Regression Equation, Linear Range of Concentration) related to the individual determination of DIP and PAR by cyclic voltammetry using the carbon paste electrode are summarized in Table 1. The plots of the anodic current peak against DIP or PAR concentrations were linear in a wide range of concentration, observing a better sensitivity for PAR.

\section{Multivariate calibration methodology}

As can be seen from the cyclic voltammetric studies, some redox peaks for DIP and PAR are overlapped which complicates their simultaneous determination by cyclic voltammetry using univariate methods. To overcome this problem, a multivariate calibration methodology based on Partial Least Square Regression (PLSR) using the Differential Pulse Voltammetry (DPV) was proposed. The use of DPV technique was justified by its higher sensitivity (compared to the cyclic voltammetry), which causes better separation between the redox peaks. Therefore, it minimizes errors for simultaneous determination of the species.

The differential pulse voltammograms for DIP, obtained in the same potential range used for the $\mathrm{CV}$ studies, showed four anodic peaks at $0.35 ; 0.65,0.82$ e $1.0 \mathrm{~V} v s$. $\mathrm{Ag} / \mathrm{AgCl}$. In contrast, the DPV of PAR showed only one extremely defined anodic peak at $0.64 \mathrm{~V}$, similar to that obtained by cyclic voltammetry technique (Figure 4).

In the calibration step, a group composed by 25 standard mixtures containing PAR and DIP were analyzed by differential pulse voltammetry (potential scan between $-0.1 \mathrm{~V}$ and $1.1 \mathrm{~V}$ ) using a carbon paste electrodes. The current data of the voltammograms (matrix $\mathrm{x}$ ) were correlated with the respective known concentrations of the analytes (PAR and DIP $1.0 \times 10^{-4} \mathrm{~mol} \mathrm{~L}^{-1}$ to $5.0 \times 10^{-4} \mathrm{~mol} \mathrm{~L}^{-1}$; matrix y). The data pre-treatment used in this process was mean centering and to choose the principal component number a cross validation procedure was used (leave-oneout). Four principal component were necessary to obtain the lowest RMSECV (Root Mean Squares Error of Cross Validation) showed in Figure 5A. The statistics show that this model explains approximately $95.5 \%$ of the variance from the data set and these four latent variables generate the regression coefficients with the evidence that exists an influence of the dypirone in the analytical signal of

Table 1. Analytical parameters obtained in the individual determination of paracetamol (PAR) and dypirone (DIP)

\begin{tabular}{|c|c|c|c|c|}
\hline Analyte & $\begin{array}{c}\text { LOD / } \\
\left(\mathrm{mmol} \mathrm{L}^{-1}\right)\end{array}$ & $\begin{array}{l}\text { Sensitivity / } \\
\left(\mu \mathrm{A} / \mathrm{mol} \mathrm{L}^{-1}\right)\end{array}$ & $\begin{array}{l}\text { Linear Regression } \\
\text { Equation }\end{array}$ & $\begin{array}{l}\text { Concentration Linear Range / } \\
\qquad\left(\mathrm{mmol} \mathrm{L}^{-1}\right)\end{array}$ \\
\hline PAR & 0.158 & $2.7 \times 10^{4}$ & $Y=-2.144+27077.1 X$ & 0.25 to 2.00 \\
\hline $\mathrm{DIP}(0.58 \mathrm{~V})$ & 0.167 & $1.6 \times 10^{3}$ & $Y=-0.129+1550.2 X$ & 0.25 to 2.00 \\
\hline $\operatorname{DIP}(1.0 \mathrm{~V})$ & 0.037 & $3.0 \times 10^{3}$ & $Y=-0.056+3008.14 X$ & 0.25 to 2.00 \\
\hline
\end{tabular}




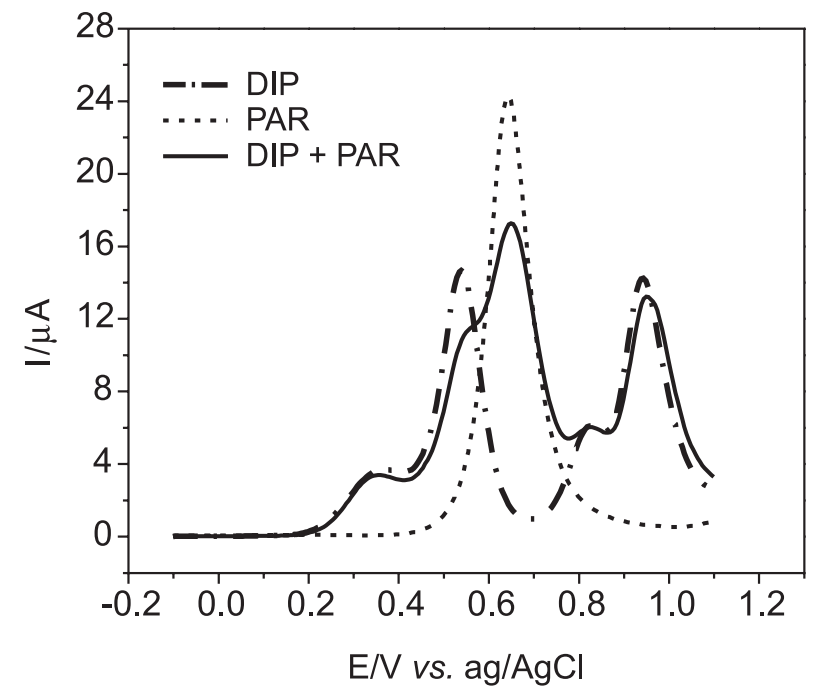

Figure 4. Differential pulse voltammograms of paracetamol (PAR), dypirone (DIP) and a mixture of DIP and PAR (both in concentration of $1 \times 10^{-3} \mathrm{~mol} \mathrm{~L}^{-1}$ ) obtained using a carbon paste electrode. Supporting electrolyte: $\mathrm{NaCl} 0.5 \mathrm{~mol} \mathrm{~L}^{-1}(\mathrm{pH}$ 6.0). Potential range of: $-0.1 \mathrm{~V}$ to $1.1 \mathrm{~V} v s$. $\mathrm{Ag} / \mathrm{AgCl}$, scan rate: $25 \mathrm{mV} \mathrm{s}^{-1}$, time pulse: $100 \mathrm{~ms}$, sensibility: $100 \mu \mathrm{A} \mathrm{V}^{-1}$.

paracetamol and vice-versa (Figure 5B). An important conclusion can be reached by analyzing the number of PLS factors required to adequate this model. It exceeds in two the theoretical limit of two expected factors as related in studies using voltammetric methods. ${ }^{46}$ This could be caused by deviations from linearity because interactions among the electroactive components and competition by the electrode surface. ${ }^{47}$

This model presented high correlation between real and predicted concentrations (Figure 6), and was applied to predict the concentration of five standard mixtures (not used in the calibration step) in duplicate. For low analytes concentrations the relative error increases to $25 \%$ for PAR (lower concentration) as shown in Table 2. Comparing the RMSEP (Root Mean Square of Error Prediction) between PAR and DIP was observed that it was lower for DIP, probably due to higher analytical information in the voltammograms (higher number of voltammetric peaks) for this analyte when compared to the electrochemical process of PAR that presented only one potential peak due to its irreversible oxidation.

The prediction results performed in duplicate (Table 2) can be used to determine the precision of multivariate model constructed. The concordance between the predicted concentrations for the duplicate showed similar precision values for both analytes.

These results were compared with univariate calibration methodology. Higher relative errors was obtained (the highest error to PAR $=140 \%$ and $\mathrm{DIP}=-28 \%$ ) for analysis of the same five standard mixtures used in the prediction
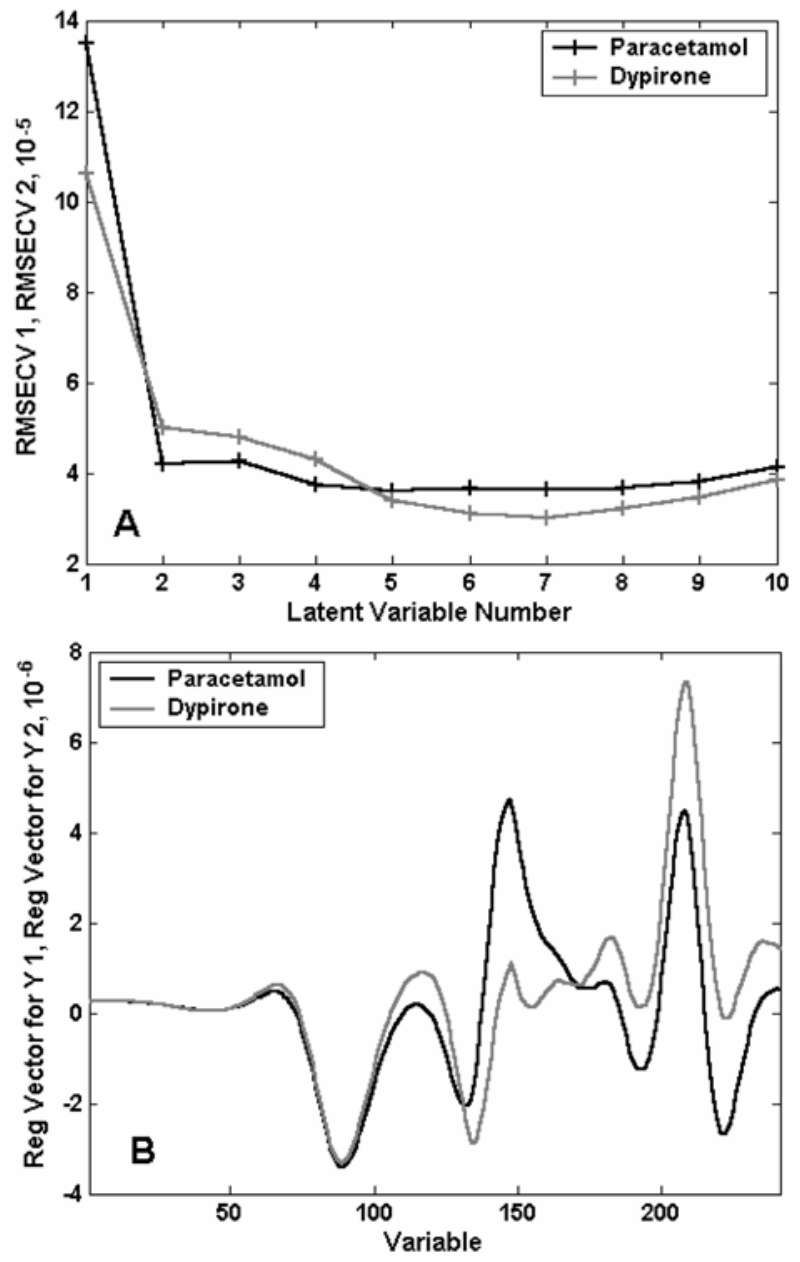

Figure 5. (A) RMSECV for PLSR model to determination of DIP and PAR; (B) Regression Coefficient with four Latent Variables in PLSR model.

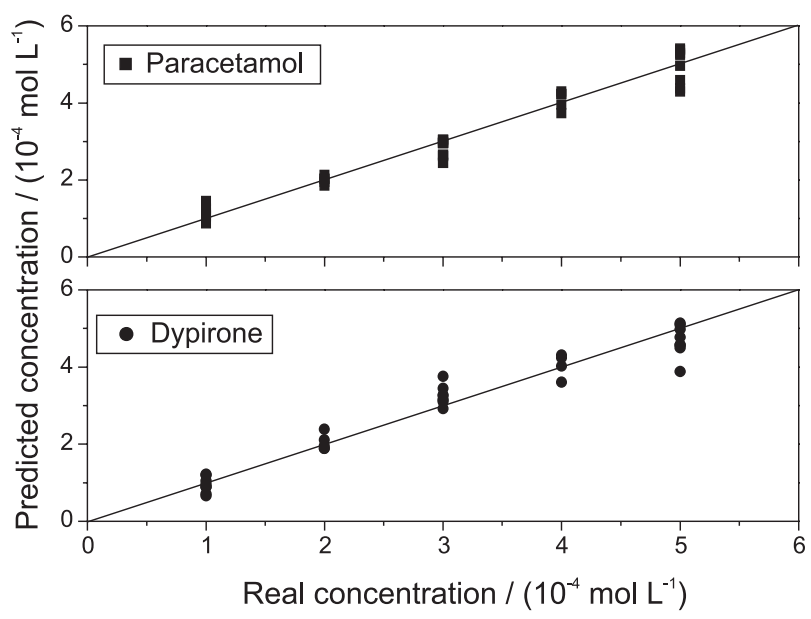

Figure 6. Relationship between predict and real concentrations of PAR and DIP.

step. The multivariate calibration methodology presented results with better prevision capacity for simultaneous determination, but the serious overlapping in the only 
Table 2. Simultaneous determination by PLSR of paracetamol (PAR) and dypirone (DIP)

\begin{tabular}{|c|c|c|c|c|c|}
\hline \multirow{2}{*}{\multicolumn{2}{|c|}{ Real Concentration / $\left(\mathrm{mmol} \mathrm{L}^{-1}\right)$}} & \multicolumn{4}{|c|}{ Multivariate method } \\
\hline & & \multicolumn{2}{|c|}{ Predicted Concentration / $\left(\mathrm{mmol} \mathrm{L}^{-1}\right)$} & \multicolumn{2}{|c|}{ Relative Error $(\%)$} \\
\hline PAR & DIP & PAR & DIP & PAR & DIP \\
\hline 0.200 & 0.450 & 0.224 & 0.502 & 11.9 & 11.5 \\
\hline 0.200 & 0.450 & 0.252 & 0.469 & 25.8 & 4.3 \\
\hline 0.350 & 0.250 & 0.393 & 0.263 & 12.3 & 5.2 \\
\hline 0.350 & 0.250 & 0.400 & 0.267 & 14.1 & 6.8 \\
\hline 0.200 & 0.300 & 0.212 & 0.298 & 6.1 & -0.6 \\
\hline 0.200 & 0.300 & 0.240 & 0.306 & 19.9 & 1.9 \\
\hline 0.400 & 0.400 & 0.437 & 0.393 & 9.2 & -1.8 \\
\hline 0.400 & 0.400 & 0.460 & 0.406 & 15.0 & 1.4 \\
\hline 0.450 & 0.200 & 0.523 & 0.202 & 16.9 & 1.2 \\
\hline 0.450 & 0.200 & 0.511 & 0.205 & 13.5 & 2.5 \\
\hline \multicolumn{2}{|c|}{$\operatorname{RMSEP}\left(\mathrm{mmol} \mathrm{L}^{-1}\right) *$} & & & 0.048 & 0.019 \\
\hline \multicolumn{2}{|c|}{ Precision [48] } & 0.015 & 0.012 & & \\
\hline
\end{tabular}

$*$ RMSEP $=\left(\left[\Sigma(\text { ypred-yreal })^{2}\right] / n\right)^{1 / 2}$.

analytical signal of paracetamol makes it difficult to resolve completely the interference of dypirone. This fact can be observed by the positive relative error for paracetamol determination in all samples of the validation set. This tendency (upper estimate) is less for the dypirone determination due to presence of the two analytical signals (oxidation process).

An alternative to improvement of the obtained results is applying the Artificial Neural Networks (ANN) to the set data. This methodology has been particularly useful in electroanalytical measurements, when the electrode response may behave in a non-linear way. ${ }^{20,49}$

\section{Conclusions}

This paper demonstrated the potentiality of differential pulse voltammetry and the multivariate methodology for simultaneous determination of paracetamol and dypirone, even using the unmodified carbon paste electrode (favorable condition to overlapping of the oxidation and reduction peaks of interest species). PLSR methodology proved to be a powerful tool for simultaneous quantification of PAR and DIP, especially considering the similarity of voltammetric response of analytes. The results obtained were satisfactory, principally at low concentration levels, with prediction of relative errors less than $26 \%$ for PAR and $12 \%$ for DIP. The methodology proposed eliminates the need for previous separation of these analytes and the modification of the carbon paste electrode to obtain a selective voltammetric response.

\section{References}

1. Canada-Canada, F.; Espinosa-Mansilla, A.; de la Pena, A. M.; J. Sep. Sci. 2007, 30, 1242.

2. Srogi, K.; Anal. Lett. 2006, 39, 231.

3. Samanidou, V. F.; Evaggelopoulou, E. N.; Papadoyannis, I. N.; J. Pharm. Biomed. Anal. 2005, 38, 21.

4. Plossl, F.; Giera, M.; Bracher, F.; J. Chromatogr. A 2006, 1135, 19.

5. Perez-Ruiz, T.; Martinez-Lozano, C.;Tomas, V.; Galera, R.; J. Pharm. Biomed. Anal. 2005, 38, 87.

6. Alnajjar, A.; AbuSeada, H. H.; Idris, A. M.; Talanta 2007, 72, 842.

7. Azhagvuel, S.; Sekar, R.; J. Pharm. Biomed. Anal. 2007, 43, 873.

8. Lopez-Flores, J.; Cordova, M. L. F. D.; Molina-Diaz, A.; Anal. Chim. Acta 2005, 535, 161.

9. Wolyniec, E.; Niedzwiedzka, U.; Kojlo, A.; Instrum. Sci. Technol. 2007, 35, 219.

10. Waseem, A.; Yaqoob, M.; Nabi, A.; Talanta 2007, 71, 56.

11. Carvalho, L. M.; Nascimento, P. C.; Bohrer, D.; Correia, D.; Bairros, A. V.; Pomblum, V. J.; Pomblum, S. G.; J. Braz. Chem. Soc. 2007, 18, 789.

12. Melo, H. C.; Seleghim, A. P. D.; Polito, W. L.; Fatibello-Filho, O.; Vieira, I. C.; J. Braz. Chem. Soc. 2007, 18, 797.

13. Ni, Y. N.; Wang, Y. R. Kokot, S.; Talanta 2006, 69, 216.

14. Matos, R. C.; Angnes, L.; Araújo, M. C. U.; Saldanha, T. C. B.; Analyst 2000, 125, 2011.

15. Bessant, C. ; Saini, S.; J. Electroanal. Chem. 2000, 489, 76. 
16. Santos, P. M.; Sandrino, B.; Moreira, T. F.; Wohnrath, K.; Nagata, N.; Pessoa, C. A.; J. Braz. Chem. Soc. 2007, 18, 93.

17. Skeika, T.; Marcovicz, C.; Nakagaki, S.; Fujiwara, S. T.; Wohnrath, K.; Nagata, N.; Pessoa, C. A.; Electroanalysis, 2007, $19,2543$.

18. Apetrei, C., Gutierez, F., Rodriguez-Mendez, M. L.; de Saja, J. A.; Sensor Actuat B-Chem. 2007, 121, 567.

19. Gonzalez, M. J. G., Renedo, O. D., Martinez M. J. A.; Talanta 2007, 71, 691 .

20. Cabanillas, A. G., Caceres, M. I. R., Canas, M. A. M., Burgillos, J. M. O., Diaz, T. G.; Talanta 2007, 72, 932.

21. Felix, F. S.; Brett, C. M. A.; Angnes, L.; J. Pharm. Biomed. Anal. 2007, 43, 1622.

22. Martin, F. L.; McLean, A. E.; Drug Chem. Toxicol. 1998, 21, 477.

23. Mugford, C. A.; Tarloff, J. B.; Toxicol. Lett. 1997, 93, 15.

24. The United States Pharmacopoeia - The National FormularyUSP 23; NF-18, Twinbrook Parkway: Rockville, 1995, p. 16.

25. Farmacopéia Brasileira, $3^{\text {rd }}$ ed., Atheneu Editora: São Paulo, 1977.

27. Burgot, G.; Auffret, F.; Burgot, J. L.; Anal. Chim. Acta 1997, $343,125$.

28. Moreira, A. B.; Oliveira, H. P. M.; Atvars, T. D. Z.; Dias, I. L. T.; Neto, G. O.; Zagatto, E. A. G.; Kubota, L. T.; Anal. Chim. Acta 2005, 539, 257.

29. Peng, W.; Li, T.; Li, H.; Wang, E.; Anal. Chim. Acta 1994, 298, 415.

30. Fatibello-Filho, O.; Lupetti, K. O.; Vieira, I. C.; Talanta 2001, 55,685 .

31. Boopathi, M.; Won, M. S.; Shim, Y. B.; Anal. Chim. Acta 2004, 512,191 .

32. Carvalho, R. M.; Freire, R. S.; Rath, S.; Kubota, L. T.; J. Pharm. Biomed. Anal. 2004, 34, 871.

33. Wangfuengkanagul, N.; Chailapakul, O.; J. Pharm. Biomed. Anal. 2002, 28, 841.
34. Wang, S. F.; Xie, F.; Hu, R. F. Sens. Actuators B 2007, 123, 495.

35. Goyal, R. N.; Singh, S. P.; Electrochim. Acta 2006, 51, 3008.

36. Aburjai, T.; Amro, B. I.; Aiedeh, K.; Abuirjeie, M.; Al-Khalil, S.; Pharmazie 2000, 55, 751.

37. Perez-Ruiz, T.; Martinez-Lozano, C.; Tomas, V.; Carpena J.; Microchem. J. 1993, 47, 296.

38. Huang, Y. M.; Zhang, C.; Zhang, X. R.; Zhang, Z. J.; J. Pharm. Biomed. Anal. 1999, 2, 817.

39. Matos, R. C.; Angnes, L.; Araújo, M. C. U.; Saldanha, T. C. B.; Analyst 2000, 125, 2011.

40. Munoz, R. A. A.; Matos, R. C.; Angnes, L.; J. Pharm. Sci. 2001, 90, 1972.

41. Perez-Ruiz, T.; Martinez-Lozano, C.; Tomas, V.; J. Pharm. Biomed. Anal. 1994, 12, 1109.

42. Wang, S-F.; Xie, F.; Hu, R-F.; Sens. Actuators B 2007, 123, 495.

43. Miner, D. J.; Rice, J. R.; Riggin, R. M.; Kissinger, P. T.; Anal. Chem. 1981, 53, 2258.

44. Kissinger, P. T.; Roston, D. A.; Van Benschoten, J. J.; Lewis, J. Y.; Heineman, W. R.; J. Chem. Educ. 1983, 60, 772.

45. Teixeira, M. F. S.; Marcolino-Júnior, L. H.; Fatibello-Filho, O.; Dockal, E. R.; Cavalheiro, E. T. G.; J. Braz. Chem. Soc. 2004, 15,803 .

46. Barthus, R. C; Mazo, L. H.; Poppi, R. J.; J. Pharm. Biomed. Anal. 2005, 38, 94.

47. Ribero, G. G.; Goicoechea, H. C.; Talanta 2003, 61, 743.

48. Braga, J. W. B.; Poppi, R. J.; Quim. Nova 2004, 27, 1004.

49. Palacios-Santander, J. M.; Cubillana-Aguilera, L. M.; NaranjoRodríguez, I; Hidalgo-Hidalgo-de-Cisneros, J. L.; Chemom. Intell. Lab. Syst. 2007, 85, 131.

Received: September 30, 2007 Web Release Date: April 30, 2008 